
terms of the Creative Commons Attribution-NonCommercial-ShareAlike licence (http://creativecommons.org/licenses/by-nc-sa/4.0/), which permits non-commercial re-use, distribution, and reproduction in any medium, provided the same Creative Commons licence is included and the original work is properly cited. The written permission of Cambridge University Press must be obtained for commercial re-use.

\title{
Race and Representation in Campaign Finance
}

\section{JACOB M. GRUMBACH University of Washington ALEXANDER SAHN University of California, Berkeley}

\begin{abstract}
$R$ acial inequality in voter turnout is well-documented, but we know less about racial inequality in campaign contributions. Using new data on the racial identities of over 27 million donors, we find an unrepresentative contributor class. Black and Latino shares of contributions are smaller than their shares of the population, electorate, and elected offices. However, we argue that the presence of ethnoracial minority candidates mobilizes coethnic donors. Results from regression discontinuity and difference-indifference designs suggest that the presence of ethnoracial minority candidates increases the share of minority contributions in US House elections. We find a reduction in white contributions to black Democrats, and to black and Latino Republicans, but little difference in overall fundraising competitiveness. Although we cannot definitively rule out alternative mechanisms that covary with candidate ethnorace, the results suggest that the nomination of minority candidates can increase the ethnoracial representativeness of campaign finance without costs to fundraising.
\end{abstract}

Mr. Obama's acceptance of his party's nomination on Thursday... signifies a powerful moment of arrival for blacks. But the milestone is especially telling for this uppercrust group, which has mobilized like never before to raise mountains of cash to power his campaign.

- "Top Black Donors See Obamas Rise as Their Own," New York Times, Aug. 28, 2008.

\section{INTRODUCTION}

$\mathbf{R}$ acial inequality in voter turnout has led to concern about biased representation in American democracy (Griffin and Newman 2008; Hajnal 2009; Hajnal and Trounstine 2005). However, we know much less about racial inequality in other forms of political participation, such as joining organizations, volunteering, or contributing money to campaigns (Schlozman, Verba, and Brady 2012; Bowler and Segura 2011, chap. 6). Unequal representation may not only arise from an unrepresentative electorate, but also from an unrepresentative contributor class (e.g., Gilens 2012; Kalla and Broockman 2016; Rhodes, Schaffner, La, and Raja 2016). Large racial

Jacob M. Grumbach (D), Assistant Professor, University of Washington, jakegrumbach@berkeley.edu.

Alexander Sahn (iD, PhD Candidate, University of California, Berkeley, asahn@berkeley.edu.

We thank Adam Bonica, Devin Caughey, Paul Frymer,Zoli Hajnal, Andy Hall, Gabe Lenz, Amy Lerman, Eric Schickler, Laura Stoker, Michael Tesler, Ali Valenzuela, Rob Van Houweling, and participants in the 2018 Money and Politics Conference at UC Irvine and the 2018 Midwest Political Science Association Conference. Alexandra Jenney, Emily Mancia, and Guillermo Perez provided excellent research assistance. Jacob M. Grumbach acknowledges support from the Ford Foundation Dissertation Fellowship. Replication files are available at the American Political Science Review Dataverse: https://doi.org/ 10.7910/DVN/PUIJIU.

Received: May 17, 2018; revised: January 31, 2019; accepted: September 17, 2019; First published online: October 24, 2019. wealth gaps and a lack of comparable social movement attention lead us to expect more racial inequality in campaign contributions than in other forms of participation.

We argue that the presence of coethnic candidates can spark greater participation for black, Latino, and Asian Americans in campaign finance. Feelings of linked fate and empowerment, as well as campaign appeals to coethnicity, may increase participation in the presence of coethnic candidates. Yet although some studies found that such an "ethnic-candidate paradigm" explains voter turnout (Barreto 2007, 2010; Bobo and Gilliam 1990; Dahl 1961; Keele et al.2017; Shah 2014; Wolfinger 1965), other studies have found that the presence of candidates of color can have minimal or even perverse effects on minority participation and the diversity of the electorate (Fraga 2016a; Gay 2001; Henderson, Sekhon, and Titiunik 2016) - such as a backlash effect among white voters to black Democratic candidates (Washington 2006). Campaign finance is a distinct form of participation from voting and coethnic contribution behavior remains largely unexamined (but see Cho 2001, 2002). Can an increase in candidates of color generate a more representative contributor class?

To answer this question, we estimated the ethnoracial identity of 27 million campaign contributors, ${ }^{1}$ whose 87 million individual contributions from 1980 to 2012 total over $\$ 33$ billion. Across this time period, we found a highly unrepresentative contributor class. Black and Latino representation in contributions is much smaller than in the general population, electorate, and elected offices, and has remained mostly static since 1980.

Although contributions are highly unrepresentative in the aggregate, we observe a more representative contributor class when candidates of color run. Candidate ethnorace is a much stronger predictor of the

\footnotetext{
${ }^{1}$ We use Census ethnoracial categorization, which itself is a sociopolitical construct that shapes and is shaped by broader political context across time (e.g., Fox and Guglielmo 2012; Junn and Masuoka 2008; Omi and Winant 2014). For a comparative perspective, see Loveman (2014).
} 
ethnoracial amount and share of contributions than district characteristics in US House elections. However, candidate ethnicity may be endogenous to demand from coethnic donors. We thus used two strategies to identify and estimate the causal effect of candidate ethnorace on coethnic contributions: a regression discontinuity design (RDD) that exploits the "as-if randomness" of close primary elections (e.g., Hall 2015) and a difference-in-difference design that exploits within-district variation across elections. Although we are unable to rule out alternative mechanisms that may produce coethnic contribution patterns, such as shared ideology, these designs help protect against confounders related to districts and electoral context.

The presence of an Asian, a black, or a Latino nominee significantly increases the proportion of Asian, black, or Latino contributions in the general election, respectively. Despite reduced white contributions to black Democrats, as well as black and Latino Republicans, candidates of color tend to be just as competitive as white candidates in overall general election fundraising. The results suggest that the presence of minority candidates can increase the ethnoracial representativeness of the contributor class in American politics and that there is little fundraising penalty for doing so.

\section{RACE, PARTICIPATION, AND REPRESENTATION}

As Schlozman, Verba, and Brady $(2012,3)$ described, equality of participation requires "proportionate input from those with politically relevant characteristics - which include such attributes as income, race or ethnicity, religion, gender, sexual orientation, age, veteran status, health, or immigrant status." At its most basic level, inequality of participation may be the result of persistent inequality of political resources, social capital, institutional trust, feelings of efficacy, and political inclusion-potentially troubling signs of tears in the social fabric of a polity (e.g., Hero 2003; Putnam 1995).

The principal concern about unequal participation, however, is that it is likely to lead to unequal political outcomes and violate norms of democratic equality (Dahl 2006; Griffin and Newman 2005; Schlozman, Verba, and Brady 2012). In recent years, scholars have turned their attention to the influence of wealthy Americans (Bartels 2009; Gilens 2012; Gilens and Page 2014; Hacker and Pierson 2010; Page, Bartels, and Seawright 2013), but with little investigation of wealth's intersection with race and ethnicity. It is well known that partisan, ideological, and policy attitudes vary greatly across racial groups (e.g., Bobo 1988; Bowler and Segura 2011; Dawson 1995; DeSipio 1998; Hajnal and Lee 2011; Krysan 2000), so racial inequality in campaign contributions is likely to produce racially biased representation of and responsiveness to public attitudes.

Research on unequal participation, especially by race, has focused overwhelmingly on the act of voting (Griffin and Newman 2007, 2008; Hajnal 2009; Hajnal and Trounstine 2005). Although elections are the main mechanism by which the public can hold politicians accountable (Key 1966), a substantial body of evidence suggests that politicians are only modestly responsive to voters (e.g., Gilens and Page 2014; Jacobs and Shapiro 2000). We know little about racial inequality in other forms of participation, such as volunteering, lobbying representatives, and contributing money to campaigns - which are, perhaps even more than voting, likely to influence the behavior of officeholders (Kalla and Broockman 2016; Schlozman, Verba, and Brady 2012). ${ }^{2}$

There are reasons to expect Americans of color to be severely underrepresented in the contributor class. The legacies of slavery and subsequent political and economic exclusion of people of African, Latin American, and Asian descent have led to inequality in the distribution of "political resources" such as money, time, and information across racial groups (Brady, Verba, and Schlozman 1995; Verba et al. 1993). ${ }^{3}$ But even compared with other forms of participation such as voting, contributing may be especially dominated by white Americans. Although wealth predicts one's likelihood of voting, it is a much stronger predictor of donating ( $\mathrm{La}$ Raja and Schaffner 2015; Rhodes, Schaffner, La, and Raja 2016). The large and persistent racial gaps in income and wealth (Blau and Graham 1990; Oliver and Shapiro 2006) may generate a starker racial gap in contributing than in other forms of participation. ${ }^{4}$ Legal scholarship has argued that wealth disparities have biased the campaign finance system against racial minorities (Overton 2000, 2001).

Emerging research addresses whether candidate ethnorace matters for overall and party-based contributions, but the ethnoracial background of campaign contributors is a critical but largely unexamined factor in assessing representation in American democracy. Existing estimates of contributions by ethnorace have used survey data (e.g., Bowler and Segura 2011; Cain, Kiewiet, and Uhlaner 1991; Lien 2010), but these estimates vary widely and are susceptible to bias (Cho 2001, 276).

\section{Ethnoracial Minority Candidates and Campaign Contributions}

Are there ways to increase the representation of people of color in campaign finance? Activists and researchers often recommend that the parties recruit and support minority candidates as a solution to unequal participation. If members of the public use shared ethnorace as a meaningful signal of shared experience or attitudes, or feel a sense of empowerment in the presence of coethnic candidates - an "ethnic-candidate paradigm"-the

\footnotetext{
${ }^{2}$ The most comprehensive assessment of the ethnoracial distribution of campaign donors is a 2015 report from the think tank Demos (Lioz 2015), but the report only provides basic descriptive analyses using the ethnoracial demographics of neighborhoods as a proxy for donor ethnorace.

${ }^{3}$ For overviews of the causes of ethnoracial inequality, see Massey and Denton (1993).

${ }^{4}$ In fact, these studies suggest that the racial wealth gap has expanded greatly since 1980 as the wealth of black families declined substantially.
} 
presence of minority candidates may encourage coethnic participation (e.g., Barreto 2007, 2010; Keele et al. 2017; Rocha et al. 2010; Shah 2014). ${ }^{5}$ Such an increase could lead to greater equality of participation.

Other studies have found minimal or even perverse effects of the presence of minority candidates on increasing coethnic participation or creating a more representative electorate (Fraga 2016a; Gay 2001; Henderson, Sekhon, and Titiunik 2016). For instance, the presence of black candidates appears to increase white turnout more than black turnout, resulting in an overall whiter electorate and reducing Democratic vote shares on average (Washington 2006). Evidence of the effect of candidate ethnorace on producing more ethnoracially representative electorates is mixed.

We argue that coethnic empowerment and the ethniccandidate paradigm are especially likely to occur in campaign finance. We theorize "push" and "pull" factors that may generate patterns of coethnic contributing. In the aggregate, we are likely to observe coethnic contributing because ethnorace is a strong predictor of party identification, ideology, and geography; we aim to avoid these confounders with our research designs. We focus here on reasons that shared ethnorace, all else equal, may influence contributing.

A principal "push" factor, driven by contributors, is based on potential donors' feelings of linked fate. Linked fate is the belief that one's individual experience is tied to the collective experience of the ethnoracial group, and greater feelings of linked fate predict support for coethnic candidates among African American and Latino voters (Dawson 1995; McConnaughy et al. 2010; Wallace 2014). Individuals with strong feelings of linked fate may, in pursuit of self-interest, donate to coethnic politicians. Factors that are positively correlated with contributing, such as education and socioeconomic status, have been found to be positively correlated with feelings of linked fate among African Americans (Dawson 1995; Gay 2004; Simien 2005; Tate 1994). There is also evidence that politicians from marginalized identity groups tend to exert greater effort to represent and improve the standing of their group in society (e.g., Broockman 2013; Dawson 1995; Logan 2018).

Linked fate may complement perceptions of ethnoracial group competition among potential donors. In local and national contexts, individuals perceive their ethnoracial group to be engaged in competition with other groups for economic and political resources (e.g., Gay 2006; Kim 2000; McClain et al. 2006; Sanchez 2008). Perceptions of out-groups as competitive threats, whether based on stereotyping or feelings of collective alienation (Bobo and Hutchings 1996), can increase incentives to support coethnic candidates over candidates from other ethnoracial groups.

Contributions to coethnic candidates may also serve expressive, rather than self-interested, motivations. Contributing, like voting, may "serve as a positive

\footnotetext{
${ }^{5}$ A related literature investigates the relationship between descriptive representation (focusing on officeholders) and ethnoracial minority empowerment (e.g., Banducci, Donovan, and Karp 2004).
}

affirmation of identity group membership or as an expression of group solidarity and support, both of which convey psychological benefits" (Horowitz 1985; Jackson 2011; Valenzuela and Michelson 2016,618). Donors often explain their motivations for contributing in terms of linked fate, identity expression, and empowerment. In 2016, for instance, the Los Angeles Times interviewed Lily Lee Chen, one of many Asian Americans who contributed large sums to John Chiang's campaign in California. Chen explained her contribution with empowerment theory: "He would serve as a model for all the Chinese American young people who have political aspirations and want to be good public servants" (quoted in Willon 2016).

Campaigns are also likely to create "pull" factors by appealing to potential donors' identities in solicitations and appeals for contributions. Campaign appeals to coethnicity may prime feelings of linked fate or increase identity strength by "selectively reinforc[ing] the preexisting identity" (Jackson 2011; Valenzuela and Michelson 2016; Rogers, Fox, and Gerber 2013, 100). ${ }^{6}$ Prior studies have investigated the role of "ethnically angled advertisements" in campaigns, such as, in the case of the Latino community, television commercials featuring Latino narrators, pictures of Latinos, and descriptions of a candidate's connections to the Latino community (e.g., Abrajano 2010; Soto and Merolla 2006) - appeals that are likely to be more effective when the candidate is also Latino (Barreto 2007, 2010). This kind of appeal may extend to campaign finance. Political action committees (PACs) further facilitate coethnic fundraising. According to the mission statement of Latino Victory Fund PAC, the organization "identifies, recruits, and develops candidates for public office while building a permanent base of Latino donors to support them."

Candidates also contact and solicit contributions from individuals in their social, educational, and professional networks (Bonica 2017a, 2017b). Such networks, including at the most elite levels of business and education, are shaped by ethnoracial identity (Allen, Epps, and Haniff 1991; McPherson, Smith-Lovin, and Cook 2001). Lawyers have long been the majority of American political candidates and officeholders, which may be explained in part by lawyer candidates' unique ability to tap their professional networks for funds and other support (Bonica 2017b). Only in recent decades, law schools have been open to black Americans (Gellhorn 1968), and de facto barriers for people of color in the legal profession persist even as de jure barriers have declined (Kornhauser and Revesz 1995; Nussbaumer 2006). In turn, during the 1960s and 70s lawyers of color created a plethora of professional organizations to facilitate development and networking, such as the National Conference of Black Lawyers and the Hispanic National Bar Association. Similar coethnic organizations exist in business, such as Latino

\footnotetext{
${ }^{6}$ These push and pull factors may interact. There is evidence that the effect of ethnoracial identity-based appeals by campaigns and organizations is conditional on individuals' strength of group identity (Valenzuela and Michelson 2016).
} 
chambers of commerce, and education, such as alumni networks of historically black colleges and universities. These organizations connect relatively financially welloff individuals who share an ethnoracial identity and are thus ideal locations for candidates to solicit contributions from coethnic donors.

Finally, campaign finance institutions may facilitate greater coethnic behavior than do electoral institutions. Whereas an individual's ability to vote for coethnic candidates is largely determined by his or her electoral district, he or she can choose whom to donate to among hundreds of candidates in any given cycle. This allows donors to support "surrogate" descriptive representation from coethnic politicians who do not represent their districts (Mansbridge 1999). It also provides the opportunity for campaigns to develop national networks of coethnic contributors. For example, Bill Carrick, advisor to Loretta Sánchez (D-CA), described plans to solicit contributions from Latino individuals and organizations across the country: "We're certainly going to reach out to the Latino community in California and all across the country, as well as the groups, but we're going to have to work really hard to raise the money, and it will have to come from sources all over the place" (quoted in Drusch 2015).

On the other hand, there are reasons to expect that donors are less likely to be influenced by candidate's ethnoracial identity compared with other types of political actors. Outside party affiliation, candidate ethnorace is the most powerful and widely used heuristic for candidates' ideological and policy positions (Banducci et al. 2008; Manzano and Sanchez 2010), but visual cues such as a candidate's ethnorace appear to be most influential among individuals of low education and information (Lenz and Lawson 2011). Donors tend to be politically engaged and have high political knowledge and policy sophistication (Barber, Canes-Wrone, and Thrower 2017), all of which reduce the importance of heuristics for political decision making. In addition, the number of ethnoracial minority donors may be so minimal that there is simply too little variation across elections to observe coethnic contribution behavior. We might therefore expect the contributor class to decide to contribute based on candidates' ideological and policy positions in ways that are only weakly associated with candidates' ethnoracial identities.

We are not only interested in coethnic contributing, but also its potential to create a more racially representative contributor class. The key outcome measure for this test is the proportion of contributions from whites in an election. Black candidates may increase black contributions, but decrease Latino and Asian contributions such that the overall proportion of contributions from donors of color remains unchanged.

In addition to contribution shares by ethnorace, we also examined contribution amounts. This analysis investigates the potential for a white donor backlash to candidates of color, which could occur in two different ways: white copartisan donors being demobilized by a candidate of color or white outpartisan donors being mobilized. Research shows that the presence of a black
Democratic nominee is associated with decreased Democratic vote shares and a whiter overall electorate in just such a dynamic (Washington 2006). White backlash behaviors have also been associated with the presidency of Barack Obama (Tesler 2012,2016). In our study, increased funds from coethnic donors may be offset by decreased white contributions to the candidate or an increase in white contributions to opponents of minority candidates. Minority candidates may receive greater contributions from donors of color, but this could come at the fundraising competitiveness. ${ }^{7}$ Correspondingly, we estimated the effect of a nominee's ethnorace on the amount of contributions the nominee receives by donor ethnorace, and separately, the amount of contributions to opponent of the nominee by donor ethnorace. We also tested whether, on average, ethnoracial minority candidates raise funds as competitively as their opponents. ${ }^{8}$

To our knowledge, Cho's $(2001,2002)$ studies of Asian American contributors are the only prior analyses of the association between candidate and donor ethnorace. Cho (2001) found that Asian American candidates receive greater amounts from Asian American contributors. However, Cho (2001) focused on the distinctions between contributions based on shared pan-ethnic identity and those based shared in national origin. Our current study focuses on pan-ethnic identities and, in contrast to prior research, identifies the causal effect of candidate ethnorace on the ethnoracial distribution of contributions and white contributions to the electoral opponents of candidates of color.

In this study, we use pan-ethnic conceptualizations of Asian, black, and Latino identity. Race and ethnicity are social constructs, and there are differences in the distribution of social capital and economic resources across these groups, as well as differences in the "racial formation" of Asian, black, and Latino ethnoracial identity in the United States (e.g., Omi and Winant 2014). These distinctions may generate differences in contributing. In Section A.1.1 in the Online Appendix, we apply the "ethnic-candidate paradigm" to Asian, black, and Latino Americans to generate expectations about intergroup differences in coethnic contributing. In short, Asian Americans hold greater economic capital on average, which may increase the likelihood of coethnic contributing. However, pan-ethnicidentity may also lead to greater coethnic contribution patterns. Pan-ethnic identity is more crystallized among Latino and especially among black Americans (e.g., Junn and Masuoka 2008; Mora 2014; Waters 1994).

\footnotetext{
${ }^{7}$ Barber, Butler, and Preece (2016) found that female state legislative candidates receive lower contribution amounts, on average, than their male counterparts. We are similarly attentive to the potential for a racial gap in fundraising.

${ }^{8}$ Party affiliation and identification is profoundly shaped by ethnorace in the United States. Our analyses of the causal effect of candidate ethnorace focuses mostly on the "treatment" of nominating a Democrat of ethnorace $r$ on contribution shares and amounts from donors of ethnorace $r$. Analogous estimates for Republican candidates and their Democratic opponents are provided in the Appendix.
} 


\section{DATA}

\section{Obtaining the Race and Ethnicity of Contributors}

We use an increasingly popular strategy to obtain the racial identities of individuals, extrapolation from the geographic distribution of names and ethnoracial groups in the US Census (e.g., Barreto, Segura, and Woods 2004; Henderson, Sekhon, and Titiunik 2016). In short, the method uses Bayes' Rule to calculate the probability that an individual identifies as African American, Asian, Latino, or white conditional on his or her name, based on the Census Bureau's Surname List. ${ }^{9}$ We then assign each individual the ethnoracial category with the greatest posterior probability. ${ }^{10} \mathrm{We}$ implement this procedure with the wru package in $R$ (Imai and Khanna 2016).

The measurement strategy assumes that surnames are independent of geographic location within racial groups. ${ }^{11}$ Although there are plausible ways in which this assumption could be violated, ${ }^{12}$ Imai and Khanna (2016) validated the method by predicting voters' selfreported race with high precision and demonstrating minimal association between geography and surname after conditioning on race (see also Fiscella and Fremont 2006).

Our estimates of individuals' racial identity are quite precise. Figure 1 shows the probability of each individual $i$ 's race estimate $R_{i}$, conditional on name $S_{i}$ and geography $G_{i}$, or $\operatorname{Pr}\left(R_{i} \mid S_{i}, G_{i}\right)$. The median probability is 0.887 . Note that $1-\operatorname{Pr}\left(R_{i} \mid S_{i}, G_{i}\right)$ is the probability that an individual is of any other ethnoracial identity (i.e., an individual with a 0.6 probability of being Asian American also has a 0.4 probability of being nonAsian). Noise in our measurement of contributor ethnorace may produce attenuation bias, such that our analyses underestimate coethnic contributions (e.g., Gustafson 2003), but we do not expect sources of bias that would inflate estimates of coethnic contributions. The legacy of slavery, where slaves were often given the surnames of slaveholders (Inscoe 1983), makes ethnoracial identity estimates less precise for African Americans (see Online Appendix Figure B.1). This greater error may produce downward bias in our estimates of black coethnic contributing compared with other ethnoracial groups.

Our main analyses use data from US House primary and general elections between 1980 and 2012. For

\footnotetext{
${ }^{9}$ The Census first asks whether an individual is Hispanic or Latino and then subsequently asks whether the individual is Asian/Pacific Islander, black, or white. Although a person of Latino ethnicity can be of any race, we conceptualize Latino individuals as a separate ethnoracial category such that black, white, and Asian individuals are non-Latino. This reflects the contemporary racialization of Latinos in the United States (e.g., Massey 2014; Omi and Winant 2014).

${ }^{10}$ Analyses using the probabilistic weights for each donor produce substantively equivalent results.

${ }^{11}$ We use donors' Census tracts, geocoded from their street addresses. We use state of residence when no Census tract match was available.

${ }^{12}$ For instance, interethnic marriage, which affects surnames, may vary geographically.
}

candidate ethnorace, we use a variety of data sources. We obtain data on the ethnorace of members of the US House from membership in the Congressional Black Caucus and Congressional Hispanic Caucus. Data on general election losers for the US House during the 2008-12 period are from Goggin (2017), who coded candidate ethnorace from statements of selfidentification, other publicly available and verified campaign sources, and, if no other information sources were available, $w r u$ estimates validated with candidate photos. Finally, our paid research assistants replicated the Goggin (2017) coding strategy for all House candidates from 1980 to 2008 and for primary election losers from 2008 to $2012 .^{13}$

Our measures of contributions come from the Dataset on Ideology and Money in Elections (DIME) from Bonica (2013), which compiles data from the Federal Election Commission (FEC), the Sunlight Foundation, and the National Institute for Money in State Politics. ${ }^{14}$ To construct our dataset, we aggregate individual contributions by candidate for the periods before and after the primary election. US House district demographic data are from the 1980,1990, and 2000 US Censuses (ICPSR 8091, 8903), and the Census American Community Survey (ACS) for 2005 through 2012.

\section{ESTIMATION STRATEGY}

Differences across districts may confound the relationship between candidate and contributor ethnorace. Even controlling for district demographic characteristics, unobserved confounders may shape both the ethnoracial distribution of electoral candidates and the racial distribution of donors (e.g., the ethnoracial distribution of social capital in a geographic area).

\section{Difference-in-Difference Design}

We mitigate the potential for confounding by implementing a difference-in-difference design at the district level. The difference-in-difference models take the following form, for district $i$ in year $t$. $Y_{i t}$ represents the share or $\log$ amount of donations from individuals of ethnoracial group $r$, with separate models for each ethnoracial group of donors $r \in\{$ Asian, black, Latino, white\}:

\footnotetext{
${ }^{13}$ Eleven candidates are of Native American/Alaska Native ethnicity and do not appear in the analysis.

${ }^{14}$ The Federal Election Campaign Act of 1971 requires candidates and committees to disclose the full names and mailing addresses of individual donors who contribute more than $\$ 200$ in an election cycle. Very small donors are thus not included. Using our data, we show in Online Appendix Figure B.3 that contribution size does not vary by race, but if the ethnoracial distribution of small contributions differs from that of larger donors, we may under- or overstate disparities in contributions. However, for our estimates of the effect of candidate ethnorace, bias due to this censoring is likely to be in a downward direction. Theoretically, we expect small donors to be more likely to exhibit coethnic contribution behavior because their contribution behavior is more elastic; they only donate when particularly enthusiastic.
} 


\section{FIGURE 1. Precision of Race and Ethnicity Estimates}

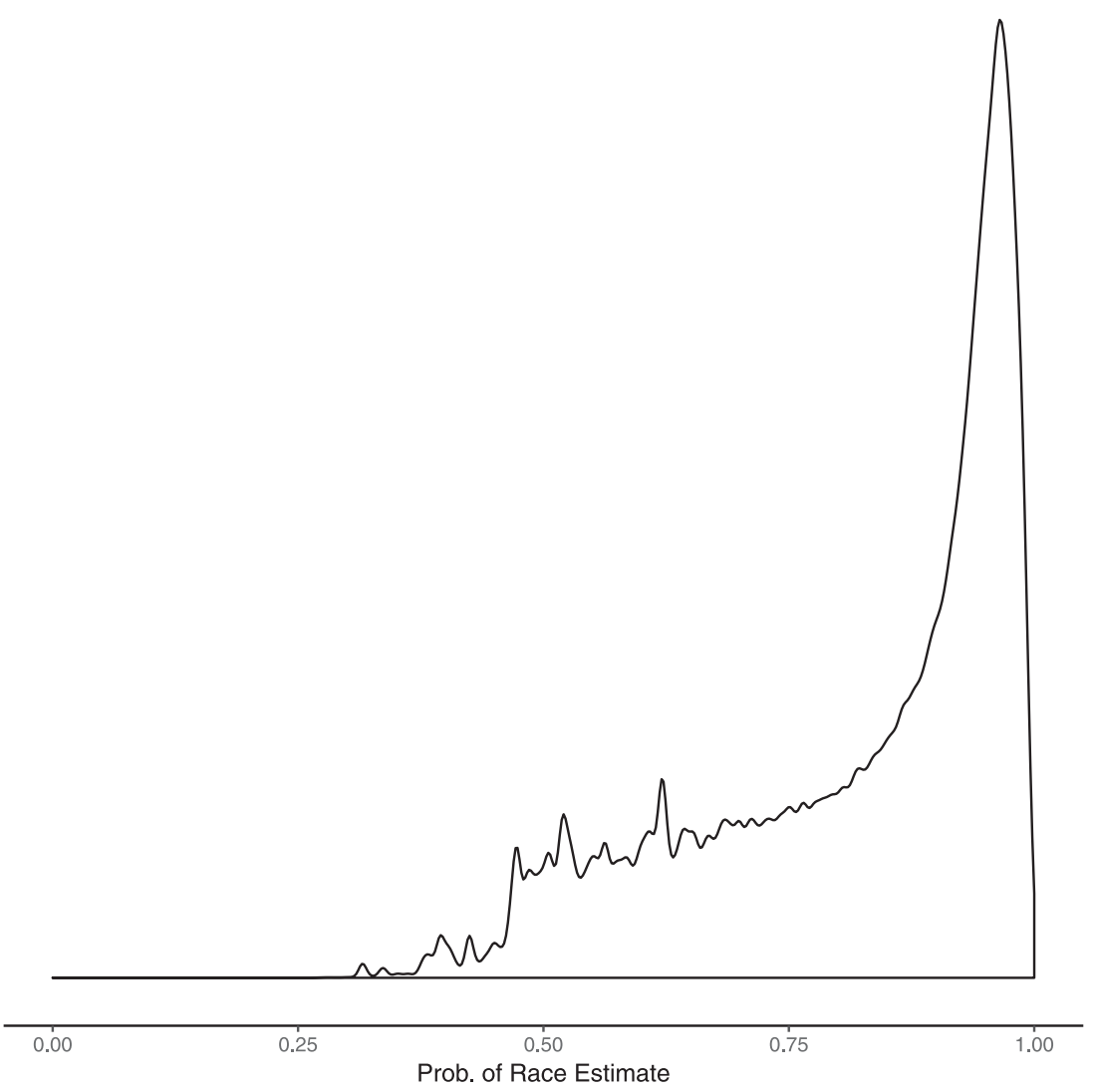

Note: Plot shows the probability that each contributor's racial identity is correctly coded, conditional on name and geographic location.

$$
\begin{aligned}
Y_{i t}= & \alpha_{i}+\delta_{t}+\beta_{1} \text { Asian.Candidate }_{i t} \\
& +\beta_{2} \text { Black.Candidate }_{i t}+\beta_{3} \text { Latino.Candidate }_{i t} \\
& +\beta X_{i t}+e_{i t} .
\end{aligned}
$$

In the equation above, $Y_{i t}$ represents the share or $\log$ amount of general election individual contributions that come from individuals of ethnorace $r$. Asian. Candidate $_{i t}$, Black.Candidate $_{i t}$, and Latino.Candidate $i t$ are dummy variables for the presence of a nominee of the ethnorace in the general election. District and year fixed effects are represented by $\alpha_{i}$ and $\delta_{t}$, ${ }^{15}$ respectively, which eliminate time-invariant confounders across districts. $X_{i t}$ is a vector of controls for district characteristics, which include district ethnoracial demographics, as well as measures of the proportion of residents in the district who are over age 65 , employed in "blue collar" occupations, ${ }^{16}$ employed in farming, employed by the federal government, active military, veterans of the military, unemployed, union members, and urban. $\beta_{1}$ through $\beta_{3}$, the quantities of interest, are

\footnotetext{
${ }^{15}$ Districts $i$ are indexed to new identifiers on redistricting.

${ }^{16}$ The Census defines blue collar as construction, extraction, and maintenance occupations.
}

the within-district effects of a candidate's ethnorace on the share or amount of contributions from donors of ethnorace $r$ in the district-year general election $i t$.

\section{Regression Discontinuity Design}

Although the identifying assumptions for the difference-in-difference design are plausible, endogeneity concerns remain. The presence of a candidate with ethnoracial identity $r$ may be endogenous to the existence and enthusiasm of coethnic contributors - potentially biasing estimates of the causal relationship between candidate ethnorace and the composition of the contributor class. We thus use an RDD to identify the causal effect of candidate ethnorace by exploiting the "as if random" assignment of primary candidates to general elections in close primary elections (Hall 2015). In particular, the quantity of interest is the effect of the presence of a general election candidate of ethnoracial identity $r$ on the share or amount of total general election contributions from donors of ethnoracial identity $r$ in US House general election $i$. This local average treatment effect (LATE) is the difference in contributions relative to the counterfactual general election candidate of a different ethnorace (in the Appendix we report additional RDD 
TABLE 1. Data and Estimation Strategies

\begin{tabular}{lcc}
\hline & Diff-in-diff & $R D D$ \\
\hline Level of analysis & District-general election & District-general election \\
Variation & Within district & Across districts \\
Election type & US House & Uouse \\
Years & $1982-2010$ & $1980-2012$ \\
Asian sample & 53 districts & 29 elections \\
Black sample & 156 districts & 153 elections \\
Latino sample & 107 districts & 116 elections \\
\hline Note: 53 districts in our data have at least one Asian primary candidate from 1982 to 2010; 156 have at least one black candidate; 107 have at \\
least one Latino candidate. Difference-in-difference model specifications have 6,070 observations (1980 and 2012 are dropped because \\
there is only one observation in these redistricting periods). ForRDD analyses, $N$ varies based on bandwidth specification. The $N$ statistics for \\
the RDD design displayed above are from specifications using the IK bandwidth. Additional specifications are provided in the Appendix.
\end{tabular}

results of subsetting to only elections in which the candidate of ethnorace $r$ faced a white opponent). In the following model, the LATE is represented by $\beta_{1}$, with separate models for each racial group $r \in\{$ Asian, black, Latino, white\}:

$$
Y_{i t}=\alpha+\beta_{1} \text { Cand.of.Race.r.Primary.Win }{ }_{i t}+f\left(V_{i t}\right)+e_{i t} .
$$

Cand.of.Race.r.Primary. Win $_{i t}$ is an indicator of whether a candidate of ethnorace $r$ won against a second-place primary finisher of a different ethnorace in a major party primary election in district $i$ in year $t . Y_{i t}$ represents the percentage or log amount of campaign funds from donors of ethnorace $r$ in the general election in district $i$ and year $t$. Substantively, then, $\beta_{1}$ is the causal effect of the "as if random" assignment of a candidate of ethnorace $r$ on the share of contributions from coethnic donors.

$f\left(V_{i t}\right)$ is a function of the forcing variable, the primary vote margin. We primarily use bandwidths from Imbens and Kalyanaraman (2012) (hereafter the IK bandwidth), Calonico, Cattaneo, and Titiunik (2014) (hereafter the CCT bandwidth), and local linear specifications of $f$, which we use to estimate the LATE of candidate ethnorace at the RDD cut point (Imbens and Lemieux 2008). We provide additional analysis in the Appendix using additional specifications of $f$. Table 1 provides further details on our difference-in-difference and RDD designs.

This design relies on the assumption that potential outcomes are smooth across the RDD cut point, that is, that the race of close-winners and close-losers in the primary election are independent of the ethnoracial distribution general election contributions. This assumption may not hold for close House general elections (Caughey and Sekhon 2011), but it is likely to hold in primary elections and other contexts (e.g., Eggers et al. 2015; Hall 2015).

Although this assumption is not directly testable, we execute placebo tests of the effect of a narrow primary win on the contributions in the primary election. If a narrow primary victory by a candidate of ethnorace $r$ is predicted by primary election fundraising, then the assignment of candidate ethnorace in the general election is unlikely to be "as if random" at the RDD cut point. Indeed, Figures A.6 and A.7 in the Online Appendix confirm that, by ethnorace and across all candidates of color, bare-winners and bare-losers of primary elections do not significantly differ in primary election fundraising. This increases our confidence that our RDD is not biased by systematic differences in candidate quality correlated with candidate ethnorace.

\section{Candidate Ethnorace as a Treatment Assignment}

We are confident that our research designs mitigate observed and unobserved confounders across districts (Henderson, Sekhon, and Titiunik 2016), such as the ethnoracial distribution of potential donors. We are less confident about potential candidate-level confounders. Politically relevant characteristics vary across ethnoracial groups at the population level such that, even within district or within a close primary election, potential nominees of different ethnoracial groups are likely to vary on additional unobserved dimensions. The appearance of coethnic contributing may occur without an "ethnic-candidate paradigm" if individuals contribute money based on these unobserved dimensions in ways that are only correlated with, not caused by shared ethnorace. ${ }^{17}$

This issue speaks to the challenge of operationalizing ethnorace in a constructivist framework (Sen and Wasow 2016), a challenge common to previous observational analyses of empowerment theory and the "ethnic-candidate paradigm" (e.g., Bobo and Gilliam 1990; Barreto 2007; Fraga 2016a, 2016b). The social constructs of race and ethnicity are made up of-and causally intertwined with-component parts, including characteristics of appearance as well as geography, social status, religion, and culture. These components contribute to and are affected by self-identification at the individual level (Davenport 2016; Thomas and Speight

\footnotetext{
${ }^{17}$ For instance, early stage obstacles and an "enthusiasm gap" may lead the pool of female candidates to be of systematically higher quality than male candidates (Fulton 2012; Lawless and Fox 2005). The pool of ethnoracial minority candidates may be shaped by similar factors.
} 
1999) and the social construct at the macro level (Omi and Winant 2014). Religion serves as a useful example. African Americans are more likely to attend Protestant churches than average, and coethnic contributing among African Americans could be driven by shared religious affiliation, not shared ethnorace. However, religion in the United States is highly racialized, ${ }^{18}$ in that it shapes and is shaped by ethnoracial categorization. In such a context, it is difficult to effectively conceptualize religious identity absent ethnorace.

We are unable to definitively rule out "non-racial" mechanisms that could lead to patterns of coethnic contributions, such as shared social class, religion, culture, ideology, and other politically relevant characteristics. We are able, however, to test for systematic differences in candidate characteristics associated with the running variable in the RDD - the candidate of color's primary vote margin. Figures A.8, A.9, and A.10 conduct these tests for sets of covariates on candidate ideology and election characteristics, career background, and religion, respectively. If contributors were choosing to donate to candidates based on ideology, for instance, we would expect to find significant differences in nominee ideology when the candidate of ethnorace $r$ barely wins or barely loses the primary. Yet we find little systematic difference in nominee ideology, as measured by DW-NOMINATE, or other candidate characteristics such as prior military service, or for election characteristics, such as CQ race forecasts or the likelihood of running in an open seat general election. By contrast, we do find significant differences, as expected, in nominee religion. Overall, despite the difficulty of isolating ethnorace as a treatment assignment, this analysis mitigates our concern about confounding from prominently studied candidate and election characteristics.

\section{THE UNREPRESENTATIVE CONTRIBUTOR CLASS}

Our first task is to compare the contributor class with the American public. Figure 2 plots the share of individual contributions in US House elections from Asian, black, and Latino donors. The remaining share, which we omit for clarity, is composed of white donors. ${ }^{19}$ As is immediately apparent, donors are overwhelmingly white. Whereas the 2010 Census reports that over one-third of Americans and $29 \%$ of eligible voters identify as ethnoracial minorities, minority donors made up only $9.3 \%$ of all individual hard money contributions between 1980 and 2012. In no election cycle does the share of individual contributions from minority donors surpass $11 \%$.

Although the overall share of funds from donors of color remains mostly static, we observe shifts among the

\footnotetext{
$\overline{18}$ As Martin Luther King Jr. described, "[T] he most segregated hour of Christian America is eleven o'clock on Sunday morning." Many surveys, such as the American National Election Study (ANES), include categories in their religious affiliation questions that distinguish between historically white and black Protestant affiliations.

${ }_{19}$ Plotting the white share renders ethnoracial minority shares largely illegible.
}

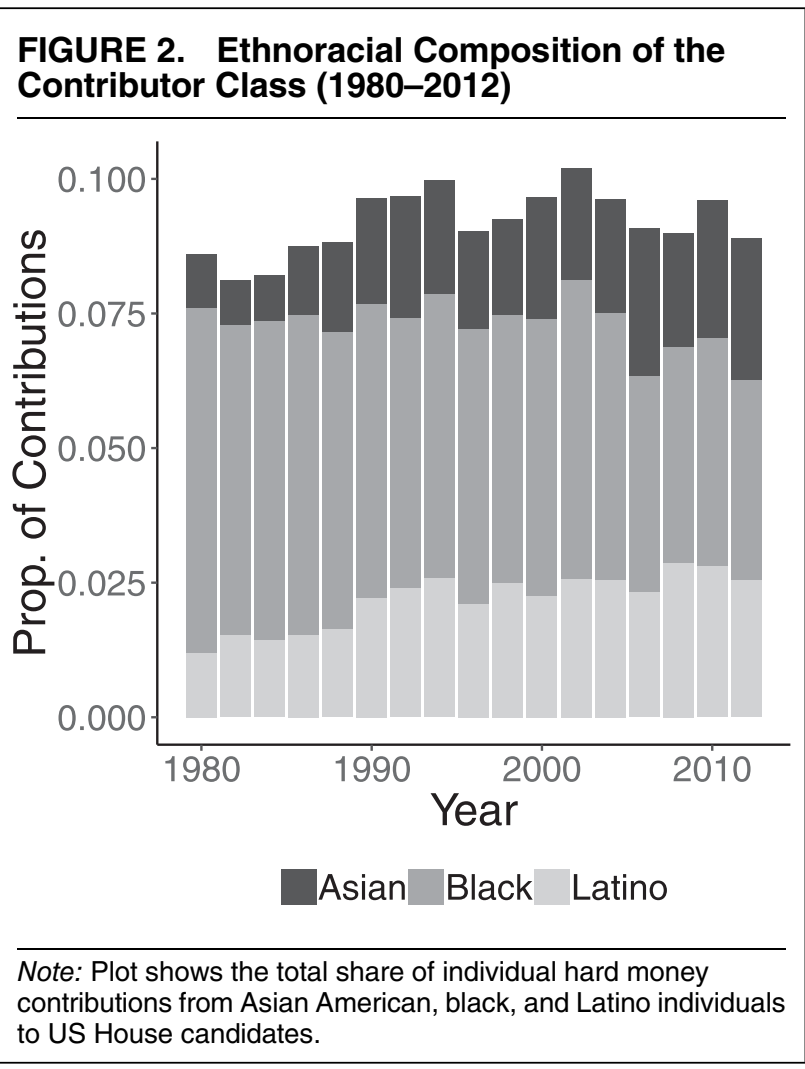

ethnoracial subgroups over time. Asian and Latino contribution shares approximately double since 1980 , which is comparable to increases in Latino and Asian electoral participation over the same period (e.g., Bowler and Segura 2011). The black contribution share, however, declines from approximately $6 \%$ to $4 \%$. This decrease stands in contrast to increased black voter turnout and descriptive representation (especially since the 1990s). Still, we argue that the declining share of black contributions is mostly unsurprising. The increase in black turnout is concentrated in presidential elections; we focus on US House elections. Furthermore, black wealth declined and the black-white wealth gap expanded over this time period.

The ethnoracial composition of donors is much less diverse than that of other groups of political actors (Figure 3). The electorate was 26.3\% nonwhite in 2012. Even elected representatives are much more racially diverse than the contributor class: 117 of the 535 members of the 115th Congress (22\%) identify as an ethnic or racial minority. The contributor class remains dominated by white Americans to an extreme and unusual degree.

\section{THE EFFECT OF CANDIDATE ETHNICITY ON CONTRIBUTIONS}

\section{Descriptive Results}

Figure 4 plots average contributions by candidate and contributor ethnorace. Descriptively, we find strong 


\section{FIGURE 3. Ethnoracial Composition of the Contributor Class Versus Electorate}

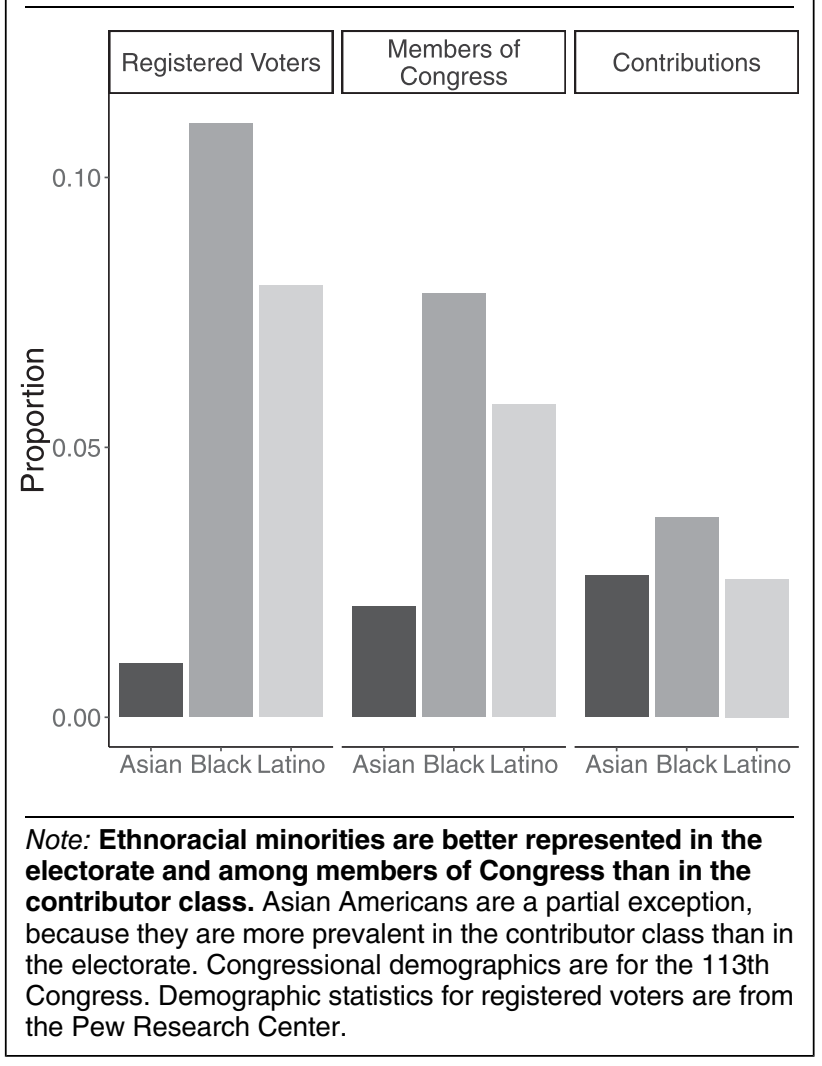

evidence of coethnic contributing. Asian, black, and Latino candidates receive greater contributions from Asian, black, and Latino donors, respectively. Black and Latino candidates receive less money from white donors, but Asian American candidates receive equal amounts as white candidates. Black candidates appear to get a much smaller increase of black donors, but as described earlier, we are less confident in our identification of black donors in the data.

We also see in Figure 4 that candidate ethnorace is correlated with overall fundraising from individual donors. Asian American candidates receive the most, followed by Latino, white, and black candidates. However, we urge caution in drawing causal conclusions from this figure because the relationship is confounded by time, geography, and, more speculatively, fundraising from nonindividual sources. Campaigns grew more expensive in recent decades as increasing numbers of Asian and Latino candidates ran for office. Campaigns in the US South, which have greater numbers of black candidates, tended to be less expensive than those in other regions during this period. ${ }^{20}$ Finally, our analysis focuses only on individual contributions; nonindividual contributions, such as PACs and party organizations, may substitute for individual contributions.

\footnotetext{
${ }^{20}$ This is likely related to the legacy of political repression in the oneparty South (Katznelson 2013).
}

\section{FIGURE 4. Average Contributions by Ethnorace}

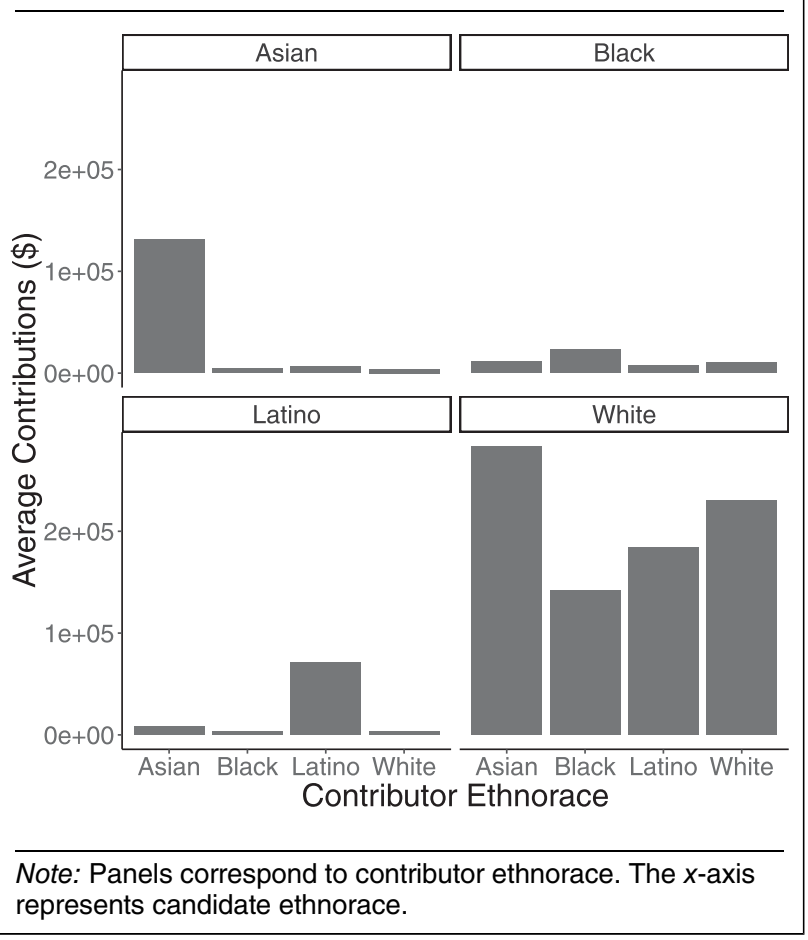

In the aggregate, we observe that candidates count on coethnic contributors for large amounts of money. We find similar results with descriptive regression models (bivariate and controlling for district demographics) in Figure A.2 in the Online Appendix. Importantly, these descriptive regressions show that the association between candidate ethnorace and the ethnoracial distribution of contributions is only minimally affected by the inclusion of district demographic covariates. In the following section, we examine whether this relationship between candidate and contributor ethnorace is causal.

\section{Difference-in-Difference Results}

Recall that the difference-in-difference design exploits variation within districts across time. Controlling for district racial demographics, we estimate the effect of nominating a Democratic candidate of ethnorace $r$ on contributions from donors of ethnorace $r$ in a given House district-election cycle, relative to a counterfactual nominee of a different ethnorace. ${ }^{21}$

Our difference-in-difference analysis first shows that the nomination of ethnoracial minority candidates leads to a more diverse set of donors. Figure 5 shows the effect of the presence of a general election candidate of ethnorace $r$ on the share of contributions from individuals of the various ethnoracial identities.

\footnotetext{
${ }^{21}$ See the Appendix for estimates using only the observations, where the counterfactual nominee is white.
} 
FIGURE 5. Effect of Candidate Ethnorace on Share of Contributions by Ethnorace

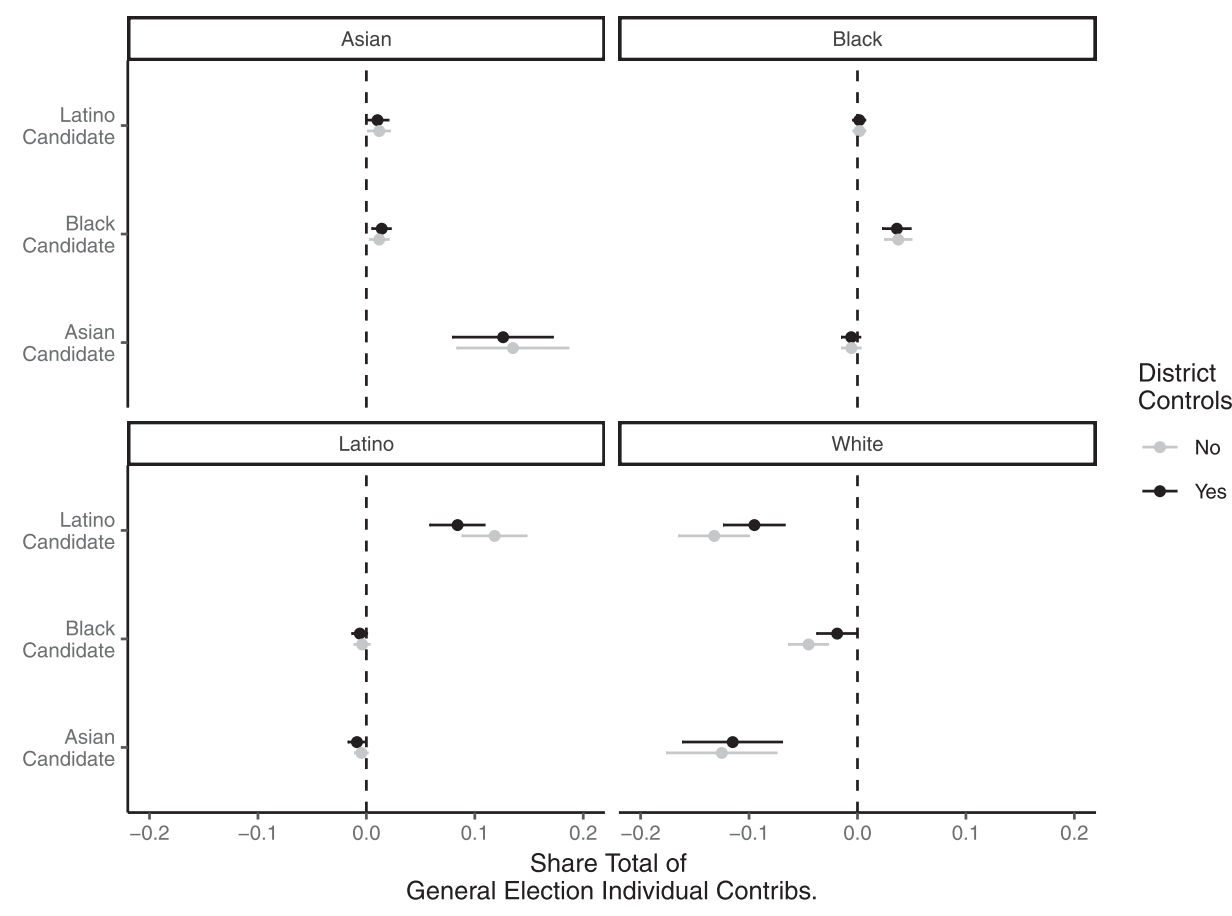

Note: The presence of a candidate of ethnorace $r$ increases the proportion of general election contributions from individuals of ethnorace $r$ in a district-year election. The omitted category is white candidate ethnorace. Models include district and year fixed effects. Estimates shown in black also control for district ethnoracial demographics. Error bars represent $95 \%$ confidence intervals. Robust standard errors are clustered by district.

The nomination of an Asian American or a Latino candidate increases the district-election's share of contributions from Asian and Latino donors by about 10 percentage points, respectively. Black nominees increase the share of black contributions by about three percentage points. $^{22}$

We find that the increase in coethnic contribution shares from Asian, black, or Latino donors substitutes for white contribution shares. These results suggest that the nomination of any nonwhite Democrat produces a less white-and, given population demographics, a more representative-contributor class. ${ }^{23}$

We find no difference in fundraising competitiveness between white and ethnoracial minority candidates. Fundraising gaps between candidates and their electoral opponents are equivalent for white and

\footnotetext{
${ }^{22}$ Note again that we estimate donors' black ethnoracial identity with less precision than individuals of other identities, which may lead estimates of black coethnic contributions to be biased downward.

${ }^{23}$ We argue that the share of money from individuals of each ethnoracial group is the theoretically relevant outcome. However, we replicate this analysis using the share of unique contributors by ethnorace, rather than share of funds, as the outcome variable in Online Appendix Figure A.3. As contribution amount does not vary by ethnorace in the sample (see Online Appendix Figure B.3), the results are nearly identical. In addition, in Online Appendix Figure A.4 we replicate the analysis subsetting only the donors with the most precise ethnoracial identity estimates (specifically, with a posterior probability of correct classification of at least 0.80 ). The results are again very similar.
}

minority candidates. Candidates of color are equally likely to achieve fundraising parity with their opponents (see Appendix Table A1). Democrats of color are slightly more competitive in their fundraising against opponents, whereas Republicans of color are slightly less competitive. Latino Democrats raise significantly more against opponents than white Democrats, but otherwise these differences are statistically indistinguishable.

Figure 6 reports the specific trends in fundraising competitiveness by candidate ethnorace. Panel (a) reports that Asian and Latino Democratic nominees increase the amount of funds from coethnic donors by more than fivefold. Although Table A.1 shows that ethnoracial minority Democrats are no less competitive against opponents in overall fundraising, we see in Figure 6 that black and Latino Democrats receive lower total amounts from white donors. This reduction of white contributions is offset by increased coethnic contributions, although not fully for black candidates.

Moreover, in Panel (b), which shows the effect of Democratic candidate ethnorace on contributions to the Republican opponent, we find that nonwhite Democrats lead to no increase of white contributions to the Republican opponent. Relative to white Democratic nominees, ethnoracial minority Democrats often decrease the amount of contributions going to the Republican opponent from the various groups of donors. Interestingly, the presence of Asian and 


\section{FIGURE 6. Effect of Democratic Candidate Ethnorace on Log Total of Contributions by Ethnorace}
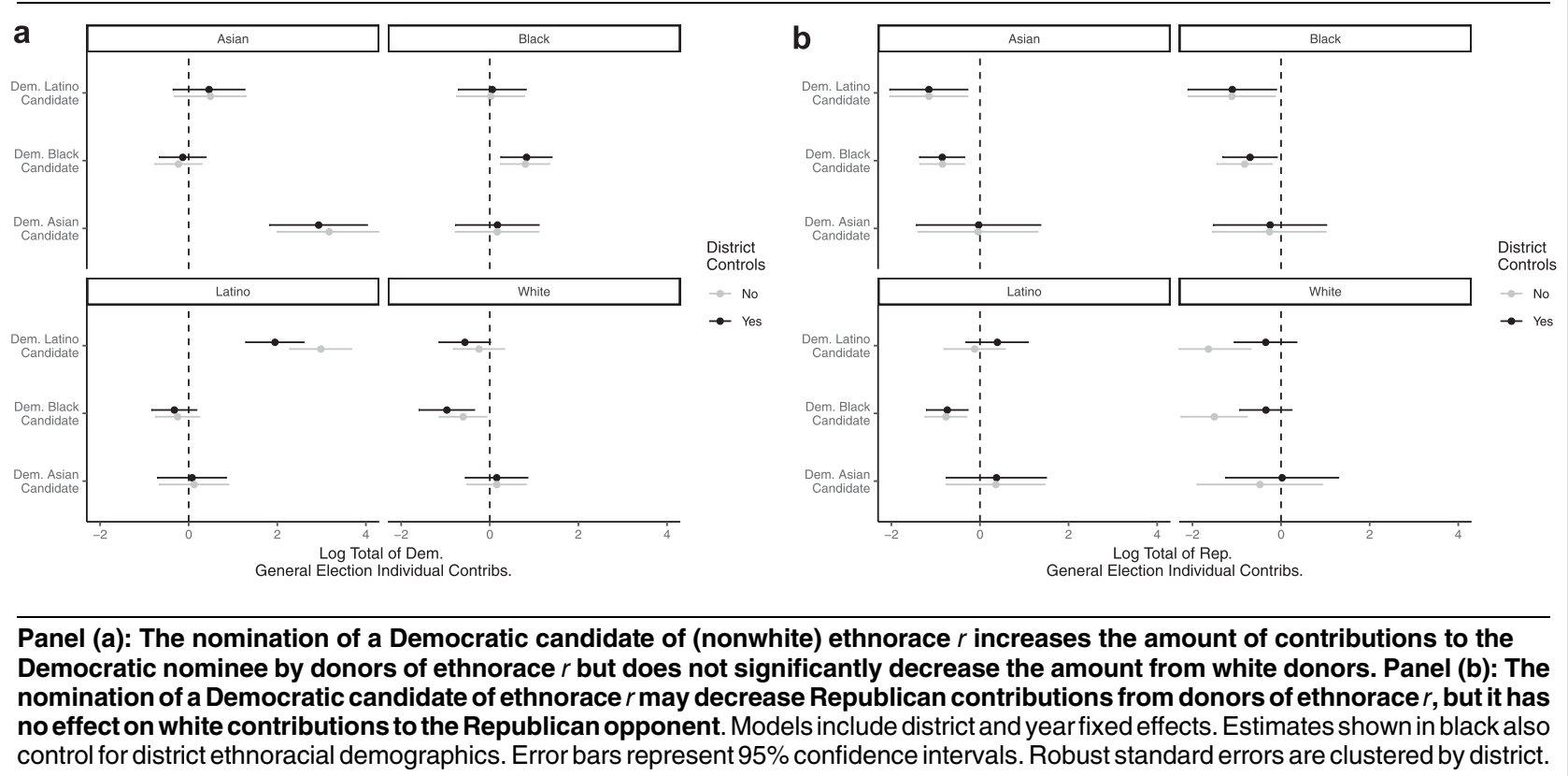

Latino Democrats appears to modestly increase Latino contributions to the Republican opponent (although this increase is significantly smaller than the increase for Latino Democrats). Taken together, Figure 6 and Table A.1 suggest that there are minimal to no fundraising costs for nominating Democratic ethnoracial minority candidates. This is in contrast to Washington (2006), who finds that white voters are less likely to vote for a black Democratic candidates and more likely to vote against her, leading to lower Democratic vote share and a whiter electorate.

As reported in the Online Appendix (Table A.1 and Figure A.5), the results are mostly consistent with respect to Republican candidates. Relative to white Republicans, Republican candidates of color receive marginally lower fundraising totals compared with their Democratic opponents. Black and Latino Republicans see reductions in white contributions compared with white Republicans, but see little difference in white contributions to their Democratic opponents. Unexpectedly, however, the nomination of Latino Republican candidates is also associated with decreased black contributions, and the nomination of black Republicans with decreased Asian contributions.

\section{Regression Discontinuity Results}

Figure 7 plots the RDD results for the effect of nominating an Asian, black, or Latino candidate (relative to a counterfactual candidate of a different ethnorace) on contributions. The $x$-axis shows the running variable, the primary election vote margin between the ethnoracial minority candidate and his or her primary opponent. Observations on the right side of the cut point receive the "treatment" of an ethnoracial minority nominee. The plots on the left show contributions made to Democratic candidates, whereas the plots on the right show contributions made to Republicans.

The RDD estimates are remarkably consistent with the difference-in-difference estimates presented earlier. For both Democrats and Republicans, the share of general election contributions from donors of ethnorace $r$ is about 10 percentage-points higher when the nominee is also of ethnorace $r{ }^{24}$

However, there are two LATE estimates that are notably distinct. The first is the estimate for black Democrats, who only modestly increase the share of contributions from black donors relative to a counterfactual non-black Democratic nominee. The second is the estimate for Asian Republicans, who see a massive (approximately 45 percentage-point) increase in Asian contribution shares compared with a counterfactual non-Asian Republican nominee.

As we described earlier, we check the robustness of the RDD findings with multiple specifications of the function of the forcing variable, the primary election vote margin. The Appendix reports additional LATE estimates using the CCT bandwidth, the IK bandwidth,

\footnotetext{
${ }^{24}$ A plausible alternative mechanism is that a close primary win signals that a candidate is more vulnerable in the general election, thus increasing coethnic contributions. Although we are unable to rule out this mechanism definitively, we find no empirical support for it. The LATE estimates from the RDD are similar to the ATE estimates from the difference-in-difference. Furthermore, the within-treatment conditional averages are quite flat, suggesting primary victory margin has little influence over the ethnoracial dynamics of general election fundraising. For only two of the six categories are slopes on the right side of the cut point (insignificantly) negative: Asian and black Republicans.
} 


\section{FIGURE 7. Regression Discontinuity Results}
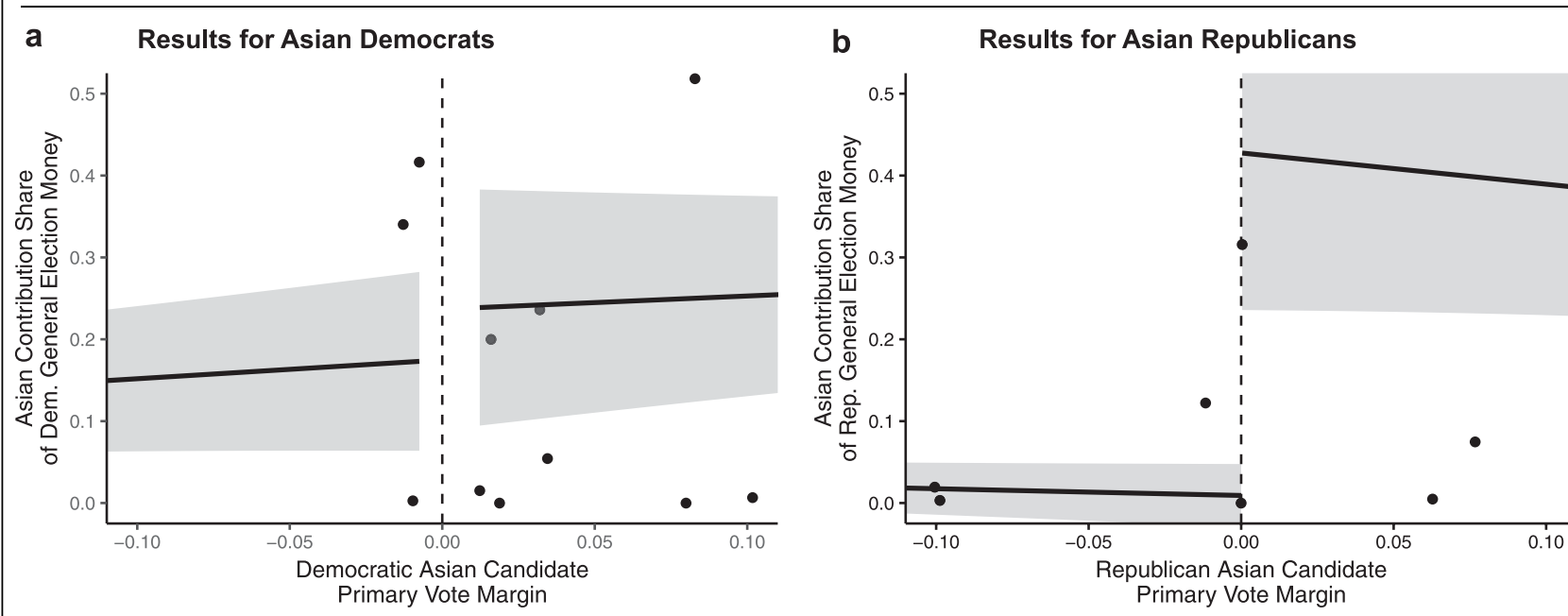

C Results for Black Democrats

d

Results for Black Republicans
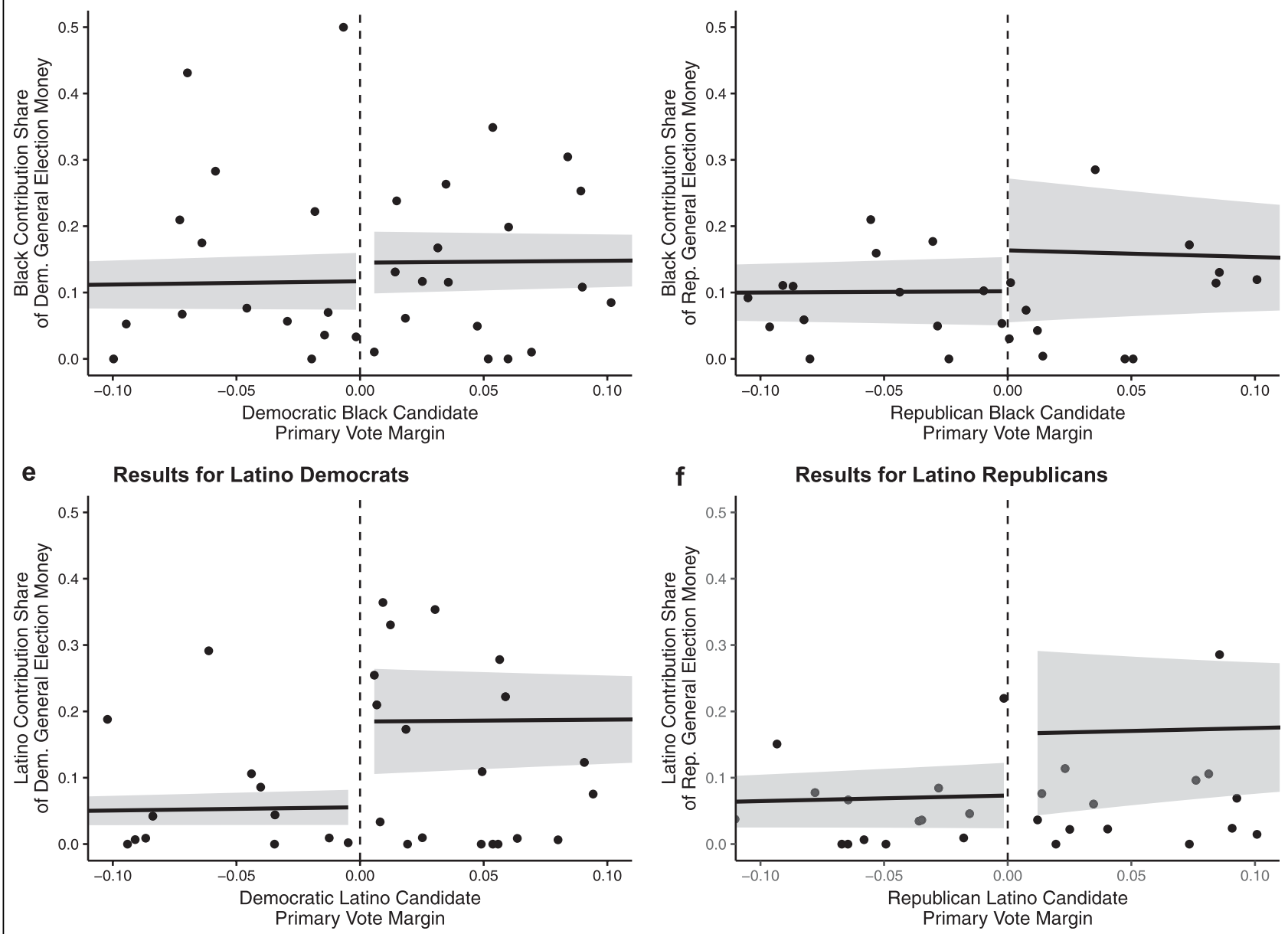

Note: Plots show LATE of nominee's ethnorace on the proportion of contributions from coethnic donors. Left column is for Democrats; right column is for Republicans. Shading represents $95 \%$ confidence intervals. Some data points used in estimates are outside the plot $y$ limits.

and local linear models with 5 and $10 \%$ bandwidths. The coethnic contribution findings are quite consistent across specifications. The nomination of candidates of color causes an increase in contributions from donors of color.

\section{CONCLUSION}

In American politics, the question of "who donates?" is closely related to the central question of "who governs?". Although racial inequality in participation, 
influence, and representation has received important scholarly attention in recent decades, the ethnoracial distribution of campaign donors has received little emphasis. We use new techniques in estimating individuals' ethnoracial identity based on their names and geographic locations to obtain the ethnoracial identities of the more than 27 million individuals who have contributed to political campaigns since 1980.

We find a racially homogeneous contributor class. The proportions of African Americans and Latinos in the public, the electorate, and even in Congress are much greater than the proportion of contributions from African Americans and Latinos. (Asian Americans are a partial exception, as their share of contributions is greater than their share of the electorate-although not the overall US public.) We estimate that only about one-tenth of contributions in recent election cycles have come from donors of color. Although the share of Asian and Latino contributions has grown since 1980, the black contribution share has declined and the overall share of contributions from individuals of color has remained mostly static.

Can running candidates of color increase the ethnoracial representativeness of the contributor class? Because candidate ethnorace is not exogenous, we address this empirical question with difference-indifference (to exploit within-district variation) and RDD designs (to exploit "as-if random" assignment of nominees' ethnorace in close primary elections). We find strong evidence that the presence of candidates of color increases the ethnoracial diversity of the contributor class in their elections. With little exception, we estimate that a nominee of a given ethnorace increases the share by 10 percentage-points and more than doubles the amount of coethnic contributions in an election. In contrast to voting (Washington 2006), we do not observe a white donor backlash to candidates of color. The presence of ethnoracial minority nominees in House elections consistently reduces the share of white contributions in the general election.

These findings provide strong evidence of an "ethniccandidate paradigm" (Barreto 2007) in campaign finance. In this paradigm, potential donors of color possess feelings of empowerment or linked fate with regard to coethnic candidates. Candidates of color make fundraising appeals to coethnic individuals, which may be facilitated by professional and political organizations. Furthermore, we emphasize how campaign finance institutions facilitate coethnic contributing relative to voting by allowing candidates to tap donors across geographic districts.

We caution against overstating the ability of greater ethnoracial diversity in campaign finance to mitigate deeply entrenched inequities. It remains unclear to what extent that greater contributions from donors of color would benefit the most marginalized members of minority communities. Research attentive to intersectionality suggests that political organizations tend to prioritize the interests of the relatively advantaged within disadvantaged identity groups (Strolovitch 2008). A similar dynamic may exist in campaign finance. Contributions from donors of color may produce greater representation for relatively well-resourced people of color but not necessarily for the intersectionally disadvantaged.

Our current inquiry generates new research questions for further investigation. The "push" and "pull" mechanisms behind coethnic contributions deserve special focus. Additional efforts should compare different psychological mechanisms, such as donors' use of linked fate or candidate ethnorace as a heuristic for ideology. The same can be said for mechanisms based in campaigns, such as the construction of national donor networks. Evidence suggests that parties and interest groups strategically mobilize certain candidates to run (Broockman 2014; Ocampo 2018), in part by structuring contribution networks (Hassell 2016). How are these processes related to candidate and contributor ethnorace?

Although it is beyond the scope of this paper, our data offer the potential to test interactions of donor and candidate race and gender. Prior research has emphasized the importance participation by women of color, especially black women, in supporting candidates of color (e.g., Philpot and Walton 2007; Tate 1994). To what extent do race and gender interact in campaign finance? Similar investigation may be also possible in other countries to illuminate the role of campaign finance in identity representation (Dancygier 2014).

Campaign finance reform also has the potential to influence the relationship between ethnoracial identity and contributions. Some public financing laws, such as that of Seattle, provide contribution vouchers to constituents - and constrain candidates' abilities to receive contributions from outside the district. It is quite plausible that these laws would increase not only the correlation between district ethnoracial demographics and the ethnoracial distribution of contributions but also its overall representativeness. Public financing also alleviates normative concerns associated with campaigns soliciting contributions from households with little disposable income.

We also hope that this study sparks greater interest in the political economy of race. Political science has seen little recent inquiry at the intersection of racial and ethnic politics and campaign finance or race and economic processes in general. Although comparative politics research has been attentive to the relationships between ethnic diversity and redistribution (e.g., Banting and Kymlicka 2006), and ethnicity and clientelism (e.g., Chandra 2007), the political economy of race in the United States, a road of inquiry paved in large part by W.E.B. Du Bois (1903), has been largely concentrated in the American political development subfield in recent years (e.g., Francis 2014; Frymer 2008; Frymer, Strolovitch, and Warren 2006; Katznelson 2013; King and Smith 2005; Schickler 2016; Spence 2012; Warren 2010). ${ }^{25}$ This study suggests that, in addition to the great strides achieved in the psychological and behavioral traditions of racial and ethnic politics research, political science would benefit from greater

\footnotetext{
${ }^{25}$ For exceptions, see Keiser, Mueser, and Choi (2004), Schram, Soss, and Fording (2010), and Hero (2016).
} 
attention to the economic, material, and elite dimensions of race and ethnicity.

\section{SUPPLEMENTARY MATERIAL}

To view supplementary material for this article, please visit https://doi.org/10.1017/S0003055419000637.

Replication materials can be found on Dataverse at: https://doi.org/10.7910/DVN/PUIJIU.

\section{REFERENCES}

Abrajano, Marisa. 2010. Campaigning to the New American Electorate: Advertising to Latino Voters. Palo Alto, CA: Stanford University Press.

Allen, Walter R., Edgar G. Epps, and Nesha Z. Haniff. 1991. College in Black and White: African American Students in Predominantly White and in Historically Black Public Universities. New York: SUNY Press.

Banducci, Susan A., Jeffrey A. Karp, Michael Thrasher, and Colin Rallings. 2008. "Ballot Photographs as Cues in Low-Information Elections." Political Psychology 29 (6): 903-17.

Banducci, Susan A., Todd Donovan, and Jeffrey A. Karp. 2004. "Minority Representation, Empowerment, and Participation." The Journal of Politics 66 (2): 534-56.

Banting, Keith, and Will Kymlicka. 2006. Multiculturalism and the Welfare State: Recognition and Redistribution in Contemporary Democracies. Oxford: Oxford University Press.

Barber, Michael, Daniel M. Butler, and Jessica Preece. 2016. "Gender Inequalities in Campaign Finance." Quarterly Journal of Political Science 11 (2): 219-48.

Barber, Michael J., Brandice Canes-Wrone, and Sharece Thrower. 2017. "Ideologically Sophisticated Donors: Which Candidates Do Individual Contributors Finance?" American Journal of Political Science 61 (2): 271-88.

Barreto, Matt. 2010. Ethnic Cues: The Role of Shared Ethnicity in Latino Political Participation. Ann Arbor, MI: University of Michigan Press.

Barreto, Matt A. 2007. "iSí Se Puede! Latino Candidates and the Mobilization of Latino Voters." American Political Science Review 101 (3): 425-41.

Barreto, Matt A., Gary M. Segura, and Nathan D. Woods. 2004. "The Mobilizing Effect of Majority-Minority Districts on Latino Turnout." American Political Science Review 98 (1): 65-75.

Bartels, Larry M. 2009. Unequal Democracy: The Political Economy of the New Gilded Age. Princeton, NJ: Princeton University Press.

Blau, Francine D., and John W. Graham. 1990. "Black-White Differences in Wealth and Asset Composition." Quarterly Journal of Economics 105 (2): 321-39.

Bobo, Lawrence. 1988. "Attitudes toward the Black Political Movement: Trends, Meaning, and Effects on Racial Policy Preferences." Social Psychology Quarterly 51 (4): 287-302.

Bobo, Lawrence, and Franklin D. Gilliam. 1990. "Race, Sociopolitical Participation, and Black Empowerment." American Political Science Review 84 (2): 377-93.

Bobo, Lawrence, and Vincent L. Hutchings. 1996. "Perceptions of Racial Group Competition: Extending Blumer's Theory of Group Position to a Multiracial Social Context." American Sociological Review 61 (6): 951-72.

Bonica, Adam. 2013. "Ideology and Interests in the Political Marketplace." American Journal of Political Science 57 (2): 294-311.

Bonica, Adam. 2017a. "Professional Networks, Early Fundraising, and Electoral Success." Election Law Journal 16 (1): 153-71.

Bonica, Adam. 2017b. "Why Are There So Many Lawyers in Congress?" Working Paper. https://ssrn.com/abstract $=2898140$.

Bowler, Shaun, and Gary Segura. 2011. The Future Is Ours: Minority Politics, Political Behavior, and the Multiracial Era of American Politics. Washington: CQ Press.

Brady, Henry E., Sidney Verba, and Kay Lehman Schlozman. 1995. "Beyond SES: A Resource Model of Political Participation." American Political Science Review 89 (2): 271-94.
Broockman, David E. 2013. "Black Politicians Are More Intrinsically Motivated to advance Blacks Interests: A Field Experiment Manipulating Political Incentives." American Journal of Political Science 57 (3): 521-36.

Broockman, David E. 2014. "Mobilizing Candidates: Political Actors Strategically Shape the Candidate Pool with Personal Appeals." Journal of Experimental Political Science 1 (2): 104-19.

Cain, Bruce E., D. Roderick Kiewiet, and Carole J. Uhlaner. 1991. "The Acquisition of Partisanship by Latinos and Asian Americans." American Journal of Political Science 35 (2): 390-422.

Calonico, Sebastian, Matias D. Cattaneo, and Rocio Titiunik. 2014. "Robust Nonparametric Confidence Intervals for RegressionDiscontinuity Designs." Econometrica 82 (6): 2295-326.

Caughey, Devin, and Jasjeet S. Sekhon. 2011. "Elections and the Regression Discontinuity Design: Lessons from Close US House Races, 1942-2008." Political Analysis 19 (4): 385-408.

Chandra, Kanchan. 2007. Why Ethnic Parties Succeed: Patronage and Ethnic Head Counts in India. Cambridge: Cambridge University Press.

Cho, Wendy K. Tam. 2001. "Foreshadowing Strategic Pan-Ethnic Politics: Asian American Campaign Finance Activity in Varying Multicultural Contexts." State Politics and Policy Quarterly 1 (3): 273-94.

Cho, Wendy K. Tam. 2002. "Tapping Motives and Dynamics behind Campaign Contributions: Insights from the Asian American Case." American Politics Research 30 (4): 347-83.

Dahl, Robert Alan. 1961. Who Governs? Democracy and Power in an American City. New Haven: Yale University Press.

Dahl, Robert Alan. 2006. On Political equality. New Haven: Yale University Press.

Dancygier, Rafaela M. 2014. "Electoral Rules or Electoral Leverage? Explaining Muslim Representation in England." World Politics 66 (2): 229-63.

Davenport, Lauren D. 2016. "The Role of Gender, Class, and Religion in Biracial Americans Racial Labeling Decisions." American Sociological Review 81 (1): 57-84.

Dawson, Michael C. 1995. Behind the Mule: Race and Class in AfricanAmerican Politics. Princeton, NJ: Princeton University Press.

DeSipio, Louis. 1998. Counting on the Latino Vote: Latinos as a New Electorate, Revised edition. Charlottesville, VA: University of Virginia Press.

Drusch, Andrea. 2015. Latino Donors Weigh How Much Support to Give Loretta Sanchez's Senate Bid: Atlantic. https://www.theatlantic. com/politics/archive/2015/05/latino-donors-weigh-how-much-supportto-give-loretta-sanchezs-senate-bid/435294/.

Du Bois, W.E.B. 1903. The Souls of Black Folk. Chicago, IL: A. C. McClurg \& Co.

Eggers, Andrew C., Anthony Fowler, Jens Hainmueller, Andrew B. Hall, and James M. Snyder. 2015. "On the Validity of the Regression Discontinuity Design for Estimating Electoral Effects: New Evidence from over 40,000 Close Races." American Journal of Political Science 59 (1): 259-74.

Fiscella, Kevin, and Allen M. Fremont. 2006. "Use of Geocoding and Surname Analysis to Estimate Race and Ethnicity." Health Services Research 41 (4 Pt 1): 1482-500.

Fox, Cybelle, and Thomas A. Guglielmo. 2012. "Defining Americas Racial Boundaries: Blacks, Mexicans, and European Immigrants, 1890-1945." American Journal of Sociology 118 (2): 327-79.

Fraga, Bernard L. 2016a. "Candidates or Districts? Reevaluating the Role of Race in Voter Turnout." American Journal of Political Science 60 (1): 97-122.

Fraga, Bernard L. 2016b. "Redistricting and the Causal Impact of Race on Voter Turnout." The Journal of Politics 78 (1): 19-34.

Francis, Megan Ming. 2014. Civil Rights and the Making of the Modern American State. New York: Cambridge University Press.

Frymer, Paul. 2008. Black and Blue: African Americans, the Labor Movement, and the Decline of the Democratic Party. Princeton, NJ: Princeton University Press.

Frymer, Paul, Dara Z. Strolovitch, and Dorian T. Warren. 2006. "New Orleans Is Not the Exception: Re-politicizing the Study of Racial Inequality." Du Bois Review: Social Science Research on Race 3(1):37-57.

Fulton, Sarah A. 2012. "Running Backwards and in High Heels: The Gendered Quality Gap and Incumbent Electoral success." Political Research Quarterly 65 (2): 303-14.

Gay, Claudine. 2001. "The Effect of Black Congressional Representation on Political Participation." American Political Science Review 95 (3): 589-602. 
Gay, Claudine. 2004. "Putting Race in Context: Identifying the Environmental Determinants of Black Racial Attitudes." American Political Science Review 98 (4): 547-62.

Gay, Claudine. 2006. "Seeing Difference: The Effect of Economic Disparity on Black Attitudes toward Latinos." American Journal of Political Science 50 (4): 982-97.

Gellhorn, Ernest. 1968. "The Law Schools and the Negro." Duke Law Journal 1968 (6): 1069-99.

Gilens, Martin. 2012. Affluence and Influence: Economic Inequality and Political Power in America. Princeton, NJ: Princeton University Press. Gilens, Martin, and Benjamin I. Page. 2014. "Testing Theories of American Politics: Elites, Interest Groups, and Average Citizens." Perspectives on Politics 12 (3): 564-81.

Goggin, Stephen N. 2017. Partisan yet Personal Politicians: Candidates' Biographies and Why They Matter. Book Manuscript.

Griffin, John D., and Brian Newman. 2005. "Are Voters Better Represented?" The Journal of Politics 67 (4): 1206-27.

Griffin, John D., and Brian Newman. 2007. "The Unequal Representation of Latinos and Whites." The Journal of Politics 69 (4): 1032-46.

Griffin, John D., and Brian Newman. 2008. Minority Report: Evaluating Political Equality in America. Chicago: University of Chicago Press.

Gustafson, Paul. 2003. Measurement Error and Misclassification in Statistics and Epidemiology: Impacts and Bayesian Adjustments: CRC Press.

Hacker, Jacob S., and Paul Pierson. 2010. "Winner-take-all Politics: Public Policy, Political Organization, and the Precipitous Rise of Top Incomes in the United States." Politics \& Society 38 (2): 152-204.

Hajnal, Zoltan, and Jessica Trounstine. 2005. "Where Turnout Matters: The Consequences of Uneven Turnout in City Politics." The Journal of Politics 67 (2): 515-35.

Hajnal, Zoltan L. 2009. "Who Loses in American Democracy? A Count of Votes Demonstrates the Limited Representation of African Americans." American Political Science Review 103 (1):37-57.

Hajnal, Zoltan L., and Taeku Lee. 2011. Why Americans Don't Join the Party: Race, Immigration, and the Failure (Of Political Parties) to Engage the Electorate. Princeton, NJ: Princeton University Press.

Hall, Andrew B. 2015. "What Happens when Extremists Win Primaries?" American Political Science Review 109 (1): 18-42.

Hassell, Hans J.G. 2016. "Party Control of Party Primaries: Party Influence in Nominations for the US Senate." The Journal of Politics 78 (1): $75-87$.

Henderson, John A., Jasjeet S. Sekhon, and Rocio Titiunik. 2016. "Cause or Effect? Turnout in Hispanic Majority-Minority Districts." Political Analysis 24 (3): 404-12.

Hero, Rodney E. 2003. "Social Capital and Racial Inequality in America." Perspectives on Politics 1 (1): 113-22.

Hero, Rodney E. 2016. "American Politics and Political Science in an Era of Growing Racial Diversity and Economic Disparity." Perspectives on Politics 14 (1): 7-20.

Hochschild, Jennifer L., and Brenna Marea Powell. 2008. "Racial Reorganization and the United States Census 1850-1930: Mulattoes, Half-Breeds, Mixed Parentage, Hindoos, and the Mexican Race." Studies in American Political Development 22 (1): 59-96.

Horowitz, Donald L. 1985. Ethnic Groups in Conflict. Berkeley, CA: University of California Press.

Imai, Kosuke, and Kabir Khanna. 2016. "Improving Ecological Inference by Predicting Individual Ethnicity from Voter Registration Records." Political Analysis 24 (2): 263-72.

Imbens, Guido, and Karthik Kalyanaraman. 2012. "Optimal Bandwidth Choice for the Regression Discontinuity Estimator." The Review of Economic Studies 79 (3): 933-59.

Imbens, Guido W., and Thomas Lemieux. 2008. "Regression Discontinuity Designs: A Guide to Practice." Journal of Econometrics 142 (2): $615-35$.

Inscoe, John C. 1983. "Carolina Slave Names: an index to Acculturation." Journal of Southern History 49 (4): 527-54.

Jackson, Melinda S. 2011. "Priming the Sleeping Giant: The Dynamics of Latino Political Identity and Vote Choice." Political Psychology 32 (4): 691-716.

Jacobs, Lawrence R., and Robert Y. Shapiro. 2000. Politicians Don't Pander: Political Manipulation and the Loss of Democratic Responsiveness. Chicago: University of Chicago Press.

Junn, Jane, and Natalie Masuoka. 2008. "Asian American Identity: Shared Racial Status and Political Context." Perspectives on Politics 6 (4): $729-40$.
Kalla, Joshua L., and David E. Broockman. 2016. "Campaign Contributions Facilitate Access to Congressional Officials: A Randomized Field experiment." American Journal of Political Science 60 (3): 545-58.

Katznelson, Ira. 2013. Fear Itself: The New deal and the Origins of Our Time. New York: WW Norton \& Company.

Keele, Luke J., Paru R. Shah, Ismail White, and Kristine Kay. 2017. "Black Candidates and Black Turnout: A Study of Viability in Louisiana Mayoral Elections." The Journal of Politics 79 (3): 780-91.

Keiser, Lael R., Peter R. Mueser, and Seung-Whan Choi. 2004. "Race, Bureaucratic Discretion, and the Implementation of Welfare Reform." American Journal of Political Science 48 (2): 314-27.

Key, Valdimer Orlando. 1966. The Responsible Electorate. Cambridge, MA: Belknap Press of Harvard University Press.

Kim, Claire Jean. 2000. Bitter Fruit: The Politics of Black-Korean Conflict in New York City. New Haven, CT: Yale University Press.

King, Desmond S., and Rogers M. Smith. 2005. "Racial Orders in American Political Development." American Political Science Review 99 (1): 75-92.

Kornhauser, Lewis A., and Richard L. Revesz. 1995. "Legal Education and Entry into the Legal Profession: The Role of Race, Gender, and Educational Debt." NYU Law Review 70: 829.

Krysan, Maria. 2000. "Prejudice, Politics, and Public Opinion: Understanding the Sources of Racial Policy Attitudes." Annual Review of Sociology 26 (1): 135-68.

La Raja, Raymond J., and Brian F. Schaffner. 2015. Campaign Finance and Political Polarization: When Purists Prevail. Ann Arbor, MI University of Michigan Press.

Lawless, Jennifer L., and Richard L. Fox. 2005. It Takes a Candidate: Why Women Don't Run for Office. New York: Cambridge University Press.

Lenz, Gabriel S., and Chappell Lawson. 2011. "Looking the Part: Television Leads Less Informed Citizens to Vote Based on Candidates Appearance." American Journal of Political Science 55 (3): 574-89.

Lien, Pei-te. 2010. Making of Asian America: Through Political Participation. Philadelphia, PA: Temple University Press.

Lioz, Adam. 2015. Stacked Deck: How the Dominance of Politics by the Affluent and Business Undermines Economic Mobility in America. Demos. http://www.demos.org/sites/default/files/publications/ StackedDeck2_1.pdf.

Logan, Trevon D. 2018. "Do Black Politicians Matter?” NBER Working Paper No. 24190. http://www.nber.org/papers/w24190.

Loveman, Mara. 2014. National Colors: Racial Classification and the State in Latin America. New York: Oxford University Press.

Mansbridge, Jane. 1999. "Should Blacks Represent Blacks and Women Represent Women? A Contingent "Yes"." The Journal of Politics 61 (3): 628-57.

Manzano, Sylvia, and Gabriel R. Sanchez. 2010. "Take One for the Team? Limits of Shared Ethnicity and Candidate Preferences." Political Research Quarterly 63 (3): 568-80.

Massey, Douglas S. 2014. "The Racialization of Latinos in the United States." In The Oxford Handbook on Ethnicity, Crime and Immigration, eds. M. Tonry and S. Bucerius. New York: Oxford University Press, 21-40.

Massey, Douglas S., and Nancy A. Denton. 1993. American Apartheid: Segregation and the Making of the Underclass. Cambridge, MA: Harvard University Press.

McClain, Paula D., Niambi M. Carter, Victoria M. DeFrancesco Soto, Monique L. Lyle, Jeffrey D. Grynaviski, Shayla C. Nunnally, Thomas J. Scotto, J. Alan Kendrick, Gerald F. Lackey, and Kendra Davenport Cotton. 2006. "Racial Distancing in a Southern City: Latino Immigrants' Views of Black Americans." The Journal of Politics 68 (3): 571-84.

McConnaughy, Corrine M., Ismail K. White, David L. Leal, and Jason P. Casellas. 2010. "A Latino on the Ballot: Explaining Coethnic Voting Among Latinos and the Response of White Americans." The Journal of Politics 72 (4): 1199-211.

McPherson, Miller, Lynn Smith-Lovin, and James M. Cook. 2001 "Birds of a Feather: Homophily in Social Networks." Annual Review of Sociology 27 (1): 415-44.

Mora, G. Cristina. 2014. Making Hispanics: How Activists, Bureaucrats, and media Constructed a New American. Chicago, IL: University of Chicago Press.

Nussbaumer, John. 2006. "Misuse of the Law School Admissions Test, Racial Discrimination, and the De Facto Quota System for 
Restricting African-American Access to the Legal Profession." St. John's Law Review 80: 167.

Ocampo, Angela X. 2018. "The Wielding Influence of Political Networks: Representation in Majority-Latino Districts." Political Research Quarterly 71 (1): 184-98.

Oliver, Melvin L., and Thomas M. Shapiro. 2006. Black Wealth, white Wealth: A New Perspective on Racial Inequality. New York: Taylor $\&$ Francis.

Omi, Michael, and Howard Winant. 2014. Racial Formation in the United States. New York: Routledge.

Overton, Spencer. 2000. "Voices from the Past: Race, Privilege, and Campaign Finance." North Carolina Law Review 79: 1541-815.

Overton, Spencer. 2001. "But Some Are More Equal: Race, Exclusion, and Campaign Finance." Texas Law Review 80: 987.

Page, Benjamin I., Larry M. Bartels, and Jason Seawright. 2013. "Democracy and the Policy Preferences of Wealthy Americans." Perspectives on Politics 11 (01): 51-73.

Philpot, Tasha S., and Hanes Walton. 2007. "One of Our Own: Black Female Candidates and the Voters Who Support Them." American Journal of Political Science 51 (1): 49-62.

Putnam, Robert D. 1995. "Bowling Alone: America's Declining Social Capital." Journal of Democracy 6 (1): 65-78.

Rhodes, Jesse H., Brian F. Schaffner, and Raymond J. La Raja. 2016. "Financial Capacity and Strategic Investors in an Era of Deregulation." Working Paper. https://scholars.org/sites/scholars/files/ schaffner_financial_capacity_and_strategic_investors_in_an_era_of _deregulation.pdf.

Rocha, Rene R., Caroline J. Tolbert, Daniel C. Bowen, and Christopher J. Clark. 2010. "Race and Turnout: Does Descriptive Representation in State Legislatures Increase Minority Voting?" Political Research Quarterly 63 (4): 890-907.

Rogers, Todd, Craig R. Fox, and Alan S. Gerber. 2013. "Rethinking Why People Vote: Voting as Dynamic Social Expression." In The Behavioral Foundations of Public Policy, ed. E. Shafir. Princeton, NJ: Princeton University Press, 91107.

Sanchez, Gabriel R. 2008. "Latino Group Consciousness and Perceptions of Commonality with African Americans." Social Science Quarterly 89 (2): 428-44.

Schickler, Eric. 2016. Racial Realignment: The Transformation of American Liberalism, 1932-1965. Vol. 153. Princeton, NJ: Princeton University Press.

Schlozman, Kay Lehman, Sidney Verba, and Henry E. Brady. 2012. The Unheavenly Chorus: Unequal Political Voice and the Broken Promise of American Democracy. Princeton, NJ: Princeton University Press.

Schram, Sanford F., Joe Brian Soss, and Richard Carl Fording. 2010. Race and the Politics of Welfare Reform. Ann Arbor, MI: University of Michigan Press.

Sen, Maya, and Omar Wasow. 2016. "Race as a Bundle of Sticks: Designs that Estimate Effects of Seemingly Immutable Characteristics." Annual Review of Political Science 19: 499-522.
Shah, Paru. 2014. "It Takes a Black Candidate: A Supply-Side Theory of Minority Representation.” Political Research Quarterly 67 (2): 266-79.

Simien, Evelyn M. 2005. "Race, Gender, and Linked Fate.” Journal of Black Studies 35 (5): 529-50.

Soto, Victoria M. DeFrancesco, and Jennifer L. Merolla. 2006. "Vota por tu futuro: Partisan mobilization of Latino voters in the 2000 presidential election." Political Behavior 28 (4): 285-304.

Spence, Lester K. 2012. "The Neoliberal Turn in Black Politics." Souls 14 (3-4): 139-59.

Strolovitch, Dara Z. 2008. Affirmative Advocacy: Race, Class, and Gender in Interest Group Politics. Chicago: University of Chicago Press.

Tate, Katherine. 1994. From Protest to Politics: The New Black Voters in American Elections. Cambridge, MA: Harvard University Press.

Tesler, Michael. 2012. "The Spillover of Racialization into Health Care: How President Obama Polarized Public Opinion by Racial Attitudes and Race." American Journal of Political Science 56 (3): 690-704.

Tesler, Michael.2016. Post-Racial or Most-Racial? Race and Politics in the Obama Era. Chicago: University of Chicago Press.

Thomas, Anita Jones, and Suzette L. Speight. 1999. "Racial Identity and Racial Socialization Attitudes of African American Parents." Journal of Black Psychology 25 (2): 152-70.

Valenzuela, Ali A., and Melissa R. Michelson. 2016. "Turnout, Status, and Identity: Mobilizing Latinos to Vote with Group Appeals." American Political Science Review 110 (4): 615-30.

Verba, Sidney, Kay Lehman Schlozman, Henry Brady, and Norman H. Nie. 1993. "Race, Ethnicity and Political Resources: Participation in the United States." British Journal of Political Science 23 (4): 453-97.

Wallace, Sophia J. 2014. "Examining Latino Support for Descriptive Representation: The Role of Identity and Discrimination." Social Science Quarterly 95 (2): 311-27.

Warren, Dorian T. 2010. "The American Labor Movement in the Age of Obama: The Challenges and Opportunities of a Racialized Political Economy." Perspectives on Politics 8 (3): 847-60.

Washington, Ebonya. 2006. "How Black Candidates Affect Voter Turnout." Quarterly Journal of Economics 121 (3): 973-98.

Waters, Mary C. 1994. "Ethnic and Racial Identities of SecondGeneration Black Immigrants in New York City." International Migration Review 28 (4): 795-820.

Willon, Phil.2016. A Vast, Mostly Untapped Donor Base Could Propel John Chiang to Become California's First Asian American Governor: Los Angeles Times. https://www.latimes.com/politics/la-polca-john-chiang-asian-american-donors-20161220-story.html.

Wolfinger, Raymond E. 1965. "The Development and Persistence of Ethnic Voting.” American Political Science Review 59 (4): 896-908. 